\title{
Grazer identity is crucial for facilitating growth of the perennial brown alga Fucus vesiculosus
}

\author{
Sonja Råberg*, Lena Kautsky \\ Department of Botany, University of Stockholm, 10691 Stockholm, Sweden
}

\begin{abstract}
The positive top-down effects on macrophytes of the removal of fouling epiphytes by herbivores versus negative bottom-up effects of enhanced epiphyte growth through nutrient enrichment are known from previous works. However, few studies have differentiated effects within the suite of herbivore species, nor have they investigated the potential negative effects of these grazers on macrophytes. We conducted a mesocosm experiment to investigate the impact of different grazer compositions (no grazers, the isopod Idotea baltica, the gastropod Theodoxus fluviatilis, and a mixture of both species) and nutrient levels (ambient and enriched) on growth of the brown alga Fucus vesiculosus. Herbivore facilitation depended on grazer identity, as only the treatments that included $T$. fluviatilis increased the growth rate of F. vesiculosus. Since I. baltica reduced the epiphyte population by the same amount as T. fluviatilis, we suggest that the grazing activities of this isopod on $F$. vesiculosus itself may have counteracted any positive effect of epiphytic removal. The same explanation may account for the similar growth rates in the treatments with T. fluviatilis alone and with both herbivorous species together, despite the lower epiphytic load in the latter treatment. In contrast, earlier published data suggested that $T$. fluviatilis facilitation is greater than that of $I$. baltica because of different epiphytic algal preferences between the grazers. Nutrient addition treatments, despite significantly increasing epiphyte load, had no effect on the growth rate of $F$. vesiculosus.
\end{abstract}

KEY WORDS: Fucus vesiculosus · Theodoxus fluviatilis · Idotea baltica · Growth rate · Grazing · Facilitation · Nutrient uptake inhibition

Resale or republication not permitted without written consent of the publisher

\section{INTRODUCTION}

In temperate rocky shore regions, slow-growing macroalgae play an important role in structuring coastal habitats. The main eutrophication effect found in these systems is an increasing amount of annual filamentous opportunistic algae (Schramm \& Nienhuis 1996, Valiela et al. 1997). These algal species are often more nutritious than the slow-growing macroalgae (Chopin et al. 1996, Pedersen \& Borum 1996), and are often favoured as food by mesoherbivores (Ravanko 1969, Goecker \& Kåll 2003, Orav-Kotta \& Kotta 2004); there are, however, trade-offs between food quality and shelter from predation (e.g. Duffy \& Hay 1991, Jormalainen et al. 2001). Slow-growing macroalgae are thus often more negatively affected by nutrient enrich- ment and at the same time more positively affected by grazing than competing opportunistic epiphytic algal species. There are also reports that reduction of epiphyte load by grazers can have positive, indirect topdown effects on brown algal growth rate and cover (Worm et al. 1999, 2000a, Jormalainen et al. 2003, Honkanen \& Jormalainen 2005), as well as reports showing indirect negative bottom-up effects through unsuccessful competition with opportunistic algal species (e.g. Kangas et al. 1982, Worm et al. 1999, Benedetti-Cecchi et al. 2001, Berger et al. 2003).

Concern about the loss of biodiversity in aquatic systems (e.g. Worm et al. 2006) has prompted increased investigation of the redundancy and/or specific effects of various herbivorous species, i.e. effects due to herbivore diversity (Duffy 2002). However, despite numer- 
ous studies of the effects of grazers on the production of structurally important macroalgae (Worm et al. 1999, 2000a, Jormalainen et al. 2003, Honkanen \& Jormalainen 2005), there is a lack of research into the effects of different herbivorous species on facilitation of macroalgal communities. Except for Duffy \& Hay (2000), the few studies that have explored the different individual versus the pooled effects of specific herbivores on macrophytes have all examined seagrass ecosystems (Duffy \& Harvilicz 2001, Duffy et al. 2001, 2003, Hays 2005). Studies of the interactive effects of different combinations of herbivores and nutrient levels are even rarer (however, see Hays 2005).

Although grazing on epiphytic algae demonstrably facilitates slow-growing brown algal production, it may also have a reverse effect due to the direct consumption of these algae (e.g. Chapman 1989, Duffy 1990, Hemmi et al. 2005). Likewise, there are field observations of negative correlations between the cover of the large, perennial brown alga Fucus vesiculosus and the abundance of the herbivorous isopod Idotea baltica (e.g. Engkvist et al. 2004, Nilsson et al. 2004). Furthermore, the small gastropod species Theodoxus fluviatilis may have a negative effect on $F$. vesiculosus growth through its removal of hyaline hairs growing on the epidermis of this fucoid (Jormalainen et al. 2003). These hairs facilitate nutrient uptake (Hurd et al. 1993), and the lower growth rate of F. vesiculosus when exposed to T. fluviatilis may result from the reduction in nutrient uptake (Jormalainen et al. 2003).

A mesocosm experiment was thus conducted to investigate the top-down impacts of two herbivorous species, viz. the isopod Idotea baltica (hereafter Idotea) and the gastropod Theodoxus fluviatilis (hereafter Theodoxus), singly and in combination, as well as the bottom-up effects of nutrient addition, on the growth rate of Fucus vesiculosus (hereafter Fucus). As illustrated in Fig. 1, we hypothesized that Idotea would decrease the growth rate of Fucus by directly grazing on Fucus thalli (H1a) and/or increase the growth rate indirectly by reducing the population of shading epiphytes $(\mathrm{H} 1 \mathrm{~b})$. In contrast, the gastropod Theodoxus was hypothesized to have a negative effect on the growth rate of Fucus through inhibiting nitrogen uptake (H2a) and/or increase Fucus growth rate indirectly through reducing the population of fouling epiphytes (H2b). We further hypothesized that a mixture of the herbivores would facilitate Fucus growth rate even more than individual herbivore species (H3), due to a complementarity effect (Loreau \& Hector 2001), resulting in the lowest epiphytic load on Fucus. In addition, nutrient enrichment was hypothesized to decrease the growth rate of Fucus (H4), due to indirect effects on the growth of fouling epiphytes.

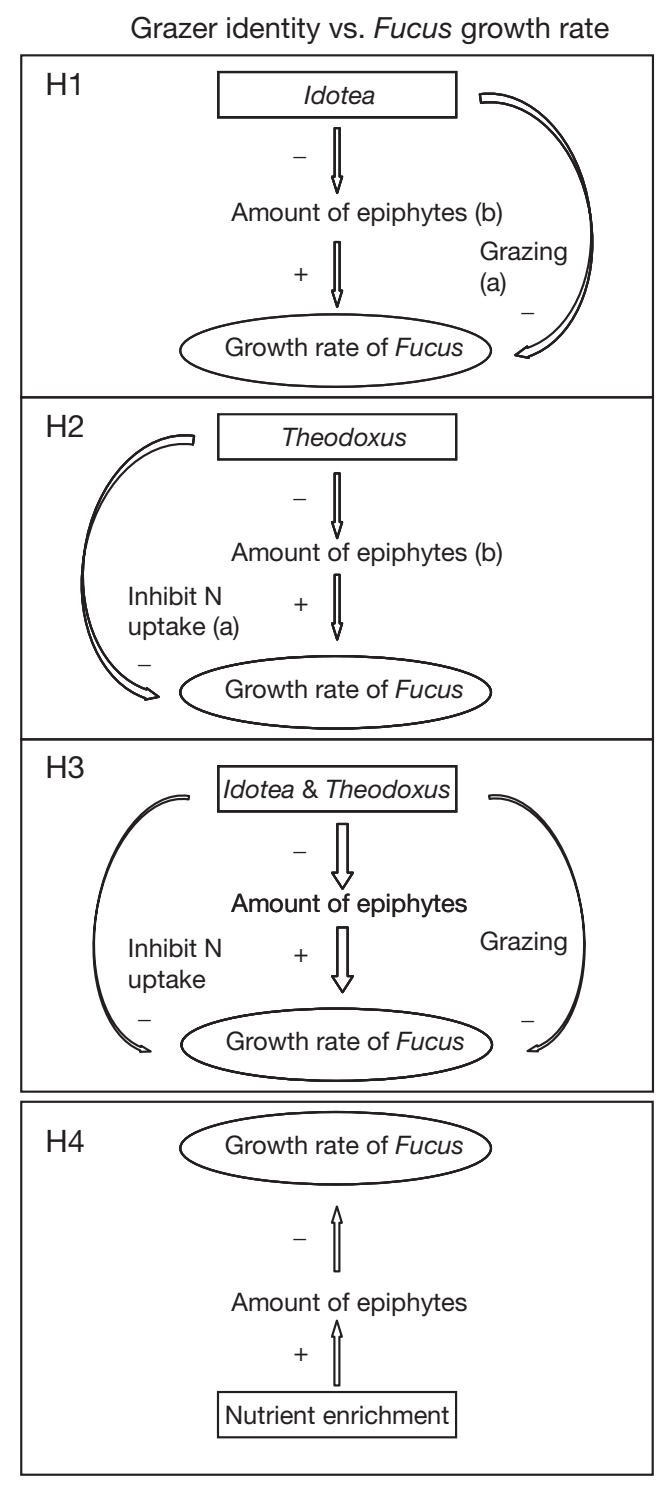

Fig. 1. Schematic of hypotheses tested experimentally. In the treatment with Idotea baltica (i.e. Idotea) as the only grazer, Fucus growth rate may be negatively affected by direct herbivore grazing (H1a) and/or indirectly and positively affected by the reduced population of fouling epiphytes (H1b). In the treatments with Theodoxus fluviatilis (i.e. Theodoxus) as the only grazer, Fucus growth rate may instead be negatively affected by inhibition of nitrogen uptake (H2a) and/or indirectly and positively affected by the gastropod's ability to reduce the epiphyte population (H2b). When I. baltica and $T$. fluviatilis are combined (i.e. the Mixed treatment), the negative effects of $I$. baltica and $T$. fluviatilis are still evident, though not as strongly as in treatments with single herbivore species, due to the reduced amounts of each herbivore species (the arrows are narrower) (H3). The reduction of the epiphyte population, due to complementarity in the utilization of epiphytic algae between the 2 herbivore species, however, is enhanced in this treatment, which in turn results in a higher growth rate of Fucus (thicker arrow) (H3). Nutrient enrichment, on the other hand, indirectly decreases the growth rate of Fucus by stimulating enhanced epiphytic growth (H4) 


\section{MATERIALS AND METHODS}

Experimental setup. The effects of nutrient enrichment and different grazer combinations on Fucus growth were tested in a factorial mesocosm experiment conducted outdoors with exposure to ambient light, temperature, and weather conditions. The experiment was carried out at the Askö Laboratory $\left(58^{\circ} 49^{\prime} \mathrm{N}, 19^{\circ} 39^{\prime} \mathrm{E}\right)$ in summer from 27 May to $1 \mathrm{July}$ 2003 (5 wk). Fucus thalli weighing approximately $220 \mathrm{~g}$ wet wt (i.e. approximately $40 \mathrm{~g}$ dry wt) and without any visible epiphytes were collected at a depth of $0.5 \mathrm{~m}$ in the vicinity of the laboratory. Each thallus was anchored to a brick with a plastic tie and placed in a circular 301 plastic container. The containers were supplied with a constant flow (one $1 \mathrm{~min}^{-1}$ ) of sand-filtered seawater (sand particle size 0.6-0.8 $\mathrm{mm}$ ) pumped from an area $120 \mathrm{~m}$ from the shore at a depth of $15 \mathrm{~m}$. Salinity and temperature in the containers approximately matched those in the sampling area (6.1 psu and $16 \pm 1^{\circ} \mathrm{C}$ ). Half of the containers received added nutrients from a commercial, slow-release NPK fertilizer (Plantacote Depot 6-M) consisting of pellets with a semipermeable polyurethane coating. This fertilizer continually released the following nutrients into the water column for at least $6 \mathrm{wk}$ : $\mathrm{N}$, as $\mathrm{NH}_{4}{ }^{+}(8.3 \%)$ and $\mathrm{NH}_{3}(5.7 \%) ; \mathrm{P}$ as water-soluble $\mathrm{P}_{2} \mathrm{O}_{5}(9 \%)$; and $\mathrm{K}$ as $\mathrm{K}_{2} \mathrm{O}(15 \%)$ (for evaluations of the method, see Worm et al. 2000b). In each container, $240 \mathrm{~g}$ of fertilizer pellets were enclosed in a polyethylene mesh roll $3 \mathrm{~cm}$ in diameter and $40 \mathrm{~cm}$ in length. To evaluate the effects of different grazer compositions, 4 grazer treatments were tested: (1) no grazers, (2) grazing by Idotea only, (3) grazing by Theodoxus only, and (4) grazing by Idotea + Theodoxus (hereafter Mixed). Each replicate of the different grazer treatments received approximately $1 \mathrm{~g}$ dry wt of grazers (the dry wt of one individual of Idotea is approximately $20 \mathrm{mg}$ and that of Theodoxus, shell-free, is approximately $2 \mathrm{mg}$ ), and the ratio between the number of Idotea and Theodoxus individuals in the Mixed treatment was $1: 15$, a ratio common in the sampling area. The Mixed treatment thus contained $40 \%$ of the total mass of Idotea introduced into the Idotea-only treatment and $60 \%$ of the total mass of Theodoxus introduced into the Theodoxus-only treatment. The most common gastropod species found on Fucus collected during the study period was Theodoxus, while Idotea was the second most common crustacean species (the most common crustacean group comprises Gammarus spp.). The abundances of Idotea and Theodoxus in the experimental setup were in the upper range of the field abundances found on Fucus thalli in the area (Råberg \& Kautsky 2007a). The grazers were transferred to the containers $1 \mathrm{wk}$ after setting up the
Fucus specimens and the nutrient diffusers, and the experiment was run for $4 \mathrm{wk}$. Due to the natural mortality of Idotea in the summer, $20 \%$ of the initial numbers of individuals in each treatment were added to the containers every week during the experiment. Faecal pellets from the grazers were removed from the containers once a week to minimize nutrient contamination. Five replicates were run for each treatment for a total of 40 containers, arranged in a randomized design in two outdoor tanks.

Analysis of nutrients in the water column. Water samples for nutrient analysis were taken from both No grazer treatments (i.e. with ambient and enriched nutrients) at the beginning, halfway and end points of the experiment. A PVC tube with an attached $50 \mathrm{ml}$ polyethylene syringe was used to sample water from the middle of the container. The water sample was immediately filtered through a $0.45 \mu \mathrm{m}$ single-use filter and frozen at $-80^{\circ} \mathrm{C}$. The concentrations of $\mathrm{NH}_{4}{ }^{+}$, $\mathrm{PO}_{4}{ }^{3-}$, and $\mathrm{NO}_{2}{ }^{-}+\mathrm{NO}_{3}{ }^{-}$were measured by means of segmented flow analysis (SFA) using an Analytic Flow solution IV (ALPKEM/OI).

Over the whole experimental period (3 sampling occasions), the average amount of $\mathrm{NH}_{4}{ }^{+}$was calculated to be $0.26 \mu \mathrm{mol} \mathrm{l}^{-1}$ in the ambient water and $3.85 \mu \mathrm{mol}$ $\mathrm{l}^{-1}$ in the nutrient-enriched water (a 15-fold increase). The $\mathrm{NO}_{2}^{-}+\mathrm{NO}_{3}^{-}$level was $0.30 \mu \mathrm{mol} \mathrm{l}{ }^{-1}$ in the ambient water and $4.13 \mathrm{mmol}^{-1}$ in the nutrient-enriched water (a 14 -fold increase). The $\mathrm{PO}_{4}{ }^{3-}$ level was $0.28 \mu \mathrm{mol} \mathrm{l}^{-1}$ in the ambient water and $0.81 \mu \mathrm{mol} \mathrm{l^{-1 }}$ in the nutrientenriched water (a 3-fold increase).

Fucus growth measurements. To study the grazing activity of Idotea, changes in the surface area of Fucus were measured by scanning five growing tips from each replicate (equivalent to approximately $120 \mathrm{~cm}^{2}$ of Fucus thallus) of the No grazers, Idotea, and Mixed treatments (i.e. all treatments except Theodoxus-only) at the start of the experiment, marking the growing tips with plastic ties, and scanning them in the same manner at the end of the experimental period. The changes in thallus area from the beginning to the end of the experiment were calculated using the program Image Tool Version 2.01 Alpha 4 and transformed to $\mathrm{cm}^{2} \mathrm{wk}^{-1}$.

In addition, the growth rate of Fucus was also measured as increase in length in order to investigate the impact of factors other than direct grazing (e.g. light and nutrient availability) in all treatments. However, this measurement also includes direct grazing to some extent when Idotea chose to graze Fucus tips. A small hole was punched $4 \mathrm{~cm}$ from the ends of 15 to 20 growing tips on each Fucus specimen at the start of the experiment. After the experiment, the tips were measured again and the mean value of the length increase of these 15 to 20 tips was recalcu- 
lated as the growth rate in $\mathrm{mm} \mathrm{wk}^{-1}$ of each Fucus thallus.

Analyses of nitrogen content in Fucus. To investigate any inhibition of nitrogen uptake due to grazing by Theodoxus, the nitrogen contents of Fucus in the No grazers, Mixed, and Theodoxus-only grazer treatments (i.e. all treatments except Idotea-only) were analysed. Before and after the experiment, 1 tip (approximately $8 \mathrm{~cm}$ long) from each replicate was cut off the Fucus thallus and dried at $60^{\circ} \mathrm{C}$ for $2 \mathrm{wk}$. After drying, the tips were ground to a fine powder and their nitrogen contents were analysed with a CHNS-932 element analyser (LECO).

Biomass of epiphytes on Fucus. At the end of the experiment, a net bag with a mesh size of $100 \mu \mathrm{m}$ was carefully pulled over the Fucus thallus in each container, which was then cut off its mounting brick. The bags were quickly transported to the laboratory and transferred to a plastic tray containing seawater, and the grazers were sorted from the Fucus. A razor blade was used to scrape the algae growing on the Fucus into the seawater in the tray, which was then filtered through a net with a mesh size of $20 \mu \mathrm{m}$. The algal epiphytes and the Fucus thalli were dried at $60^{\circ} \mathrm{C}$ for at least $2 \mathrm{wk}$, and the epiphytic load was recalculated to $\mathrm{g}$ dry wt per $100 \mathrm{~g}$ dry wt Fucus.

Grazer survival and distribution. The grazers, both those occupying the Fucus material and those left in the containers, were counted after the experiment. The number of Idotea was reduced by $17 \%$ from the initial abundance, despite the additions made during the experiment, while the number of Theodoxus was reduced by only $2 \%$. This reduction in the number of herbivores did not differ between the treatments. (A 2-way ANOVA testing effects of nutrient level and grazer composition gave p values of 0.23 to 0.44 and 0.12 to 0.93 for the reduction of Idotea and Theodoxus numbers, respectively). When counting the Theodoxus specimens, we noted that approximately half of the snails were distributed on the walls of the container and half on the Fucus itself; in contrast, the Idotea specimens occupied the Fucus thallus most of the time, only occasionally swimming in the water.

Statistical analyses. Two-way ANOVAs were used to analyse (1) the growth of Fucus and of epiphytic biomass, and (2) changes in nitrogen content over the duration of the experiment; nutrient level (ambient nutrient concentration versus nutrient enrichment) and grazer composition ( $\mathrm{n}=4$ ) were used as fixed factors. When grazer composition had a significant effect or there was a significant interaction, pairwise differences between means were further explored using Tukey's HSD test. Epiphytic biomass was third-root transformed to meet the assumption of homogeneity of variances (Cochran's test). All tests were performed using Statistica 6.1 (StatSoft).

\section{RESULTS}

\section{Effects of direct grazing on Fucus thallus area}

Growth rate measured as increase in area of Fucus thalli was not affected by either nutrient level or grazer compositions that included Idotea (i.e. the Idotea-only and Mixed treatments) (Table 1). The grazer composition factor had a p value of 0.050 (Table 1), and a posthoc test indicated $\mathrm{p}$ values of 0.07 between the No grazers and Mixed treatments, and of 0.09 between the Idotea and Mixed treatments, respectively. Contrary to what was expected, the area increase of Fucus thalli was almost the same in the treatment with no Idotea present (i.e. the No grazer control) and the treatment with the greatest abundance of Idotea (i.e. the Idoteaonly treatment) (Fig. 2A).

\section{Effects of grazing activities on Fucus nitrogen content}

The change in nitrogen content over the course of the experiment was unaffected by grazer composition (Tables 1,2). Thus, it appears that Theodoxus may not have inhibited Fucus nitrogen uptake. Instead, nitro-

Table 1. Two-way ANOVAs testing effects of nutrient level (ambient nutrients, nutrient enrichment) and grazer composition (No grazers, Idotea baltica, Theodoxus fluviatilis, and I. baltica $+T$. fluviatilis) on growth of Fucus thallus area, Fucus nitrogen content, growth of Fucus thallus length, and epiphytic algal mass

\begin{tabular}{|c|c|c|c|}
\hline Source of variation & df & $F$ & $\mathrm{p}$ \\
\hline \multicolumn{4}{|l|}{ Growth of Fucus thallus area $\left(\mathrm{cm}^{2} \mathrm{wk}^{-1}\right)$} \\
\hline Nutrient level & 1 & 0.03 & 0.596 \\
\hline Grazer composition & 2 & 3.39 & 0.050 \\
\hline Nutrient level $\times$ Grazer composition & 2 & 0.12 & 0.888 \\
\hline Residual & 24 & & \\
\hline \multicolumn{4}{|c|}{ Growth of Fucus nitrogen content ( $\%$ dry wt) } \\
\hline Nutrient level & 1 & 42.4 & $<0.001$ \\
\hline Grazer composition & 2 & 0.93 & 0.406 \\
\hline Nutrient level $\times$ Grazer composition & 2 & 2.06 & 0.149 \\
\hline Residual & 24 & & \\
\hline \multicolumn{4}{|l|}{ Fucus thallus length $\left(\mathrm{mm} \mathrm{wk}^{-1}\right)$} \\
\hline Nutrient level & 1 & 0.53 & 0.474 \\
\hline Grazer composition & 3 & 6.36 & $<0.01$ \\
\hline Nutrient level $\times$ Grazer composition & 3 & 0.04 & 0.988 \\
\hline Residual & 32 & & \\
\hline \multicolumn{4}{|c|}{ Epiphytic algal mass (g dry wt $100 \mathrm{~g}^{-1}$ dry wt Fucus) } \\
\hline Nutrient level & 1 & 31.5 & $<0.001$ \\
\hline Grazer composition & 3 & 75.7 & $<0.001$ \\
\hline Nutrient level $\times$ Grazer composition & 3 & 1.57 & 0.217 \\
\hline Residual & 32 & & \\
\hline
\end{tabular}




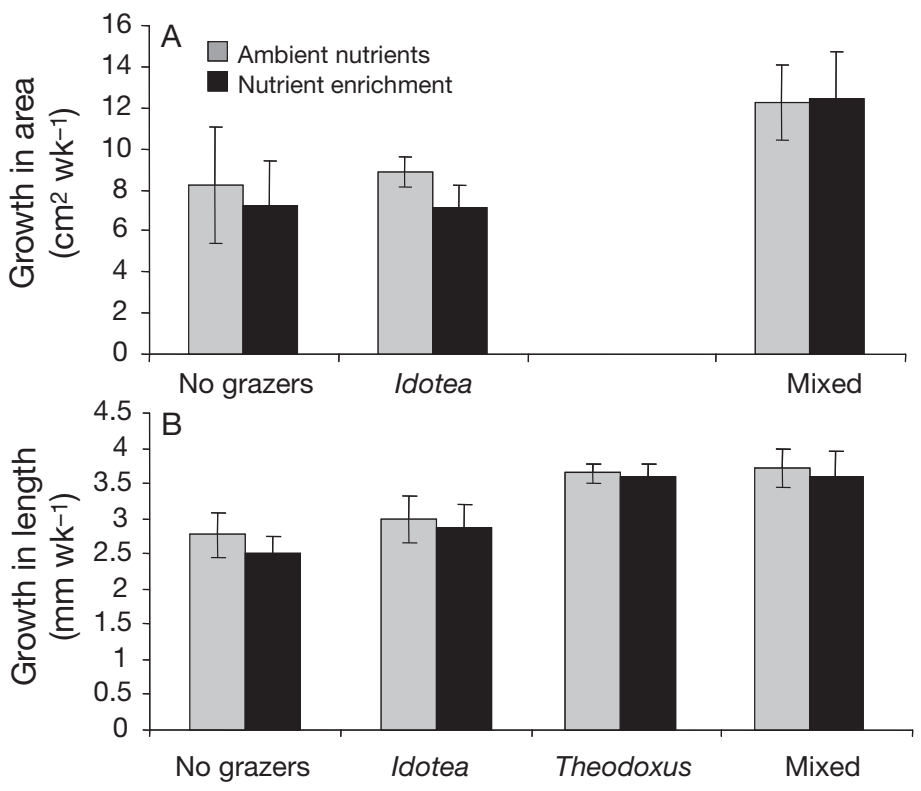

Fig. 2. Fucus vesiculosus. Growth of (A) thallus area and (B) length. The 4 grazer treatments are: No grazers, Idotea baltica (Idotea), Theodoxus fluviatilis (Theodoxus), and I. baltica $+T$. fluviatilis (Mixed). Means $\pm \operatorname{SE}(\mathrm{n}=5)$

gen content changed significantly over the study period depending on whether or not nutrients were added (Table 1), and it was only under ambient nutrient conditions that change occurred over the time course of the experiment (nitrogen content decreased, Table 2).

\section{Treatment effects on increase in Fucus thallus length}

Grazer composition had a significant effect on the growth in length of Fucus thalli (Table 1, Fig. 2B), and post hoc testing revealed a higher growth rate in the Mixed (3.65 $\mathrm{mm} \mathrm{wk}^{-1}$ ) and Theodoxus-only (3.62 mm $\mathrm{wk}^{-1}$ ) treatments than in the No grazer treatment $\left(2.64 \mathrm{~mm} \mathrm{wk}^{-1}\right)(\mathrm{p}<0.01$ in all cases). On the other hand, nutrient level had no impact on increase in thallus length (Table 1, Fig. 2B).

\section{Biomass of epiphytic algae}

Although both Fucus area and linear growth rates were unaffected by nutrient addition, the biomass of epiphytic algae (Table 3), thought to have a negative effect on Fucus growth, was significantly higher in enriched nutrient treatments (Table 1). Biomass of epiphytes also varied significantly depending on grazer composition (Table 1). Post hoc testing for grazer composition revealed differences between all grazer treat-
Table 2. Fucus vesiculosus. Percentage changes in nitrogen content (\% dry wt) under ambient and enriched nutrient conditions over the course of the experiment. The 3 grazer treatments are No grazers, Theodoxus fluviatilis (Theodoxus), and Idotea baltica + T. fluviatilis (Mixed). Means \pm SE $(n=5)$

\begin{tabular}{|lcc|}
\hline & Ambient nutrients & Nutrient enrichment \\
\hline No grazers & $-1.13 \pm 0.26$ & $0.24 \pm 0.18$ \\
Theodoxus & $-1.24 \pm 0.22$ & $0.40 \pm 0.22$ \\
Mixed & $-1.07 \pm 0.26$ & $-0.35 \pm 0.25$ \\
\hline
\end{tabular}

Table 3. Fucus vesiculosus. Epiphytic biomass (g dry wt per $100 \mathrm{~g}$ dry wt $F$. vesiculosus, means $\pm \mathrm{SE}_{;} \mathrm{n}=5$ ). The 4 grazer compositions are No grazers, Idotea baltica (Idotea), Theodoxus fluviatilis (Theodoxus), and I. baltica + T. fluviatilis (Mixed)

\begin{tabular}{|lcc|}
\hline & Ambient & Enriched \\
\hline No grazers & $4.88 \pm 0.40$ & $7.15 \pm 1.51$ \\
Idotea & $0.68 \pm 0.10$ & $2.15 \pm 0.33$ \\
Theodoxus & $0.55 \pm 0.07$ & $1.94 \pm 0.43$ \\
Mixed & $0.26 \pm 0.04$ & $0.52 \pm 0.08$ \\
\hline
\end{tabular}

ments ( $\mathrm{p}<0.001$ in all cases), except between the Idotea- and Theodoxus-only treatments $(\mathrm{p}=0.86)$. The No grazer treatment had the highest epiphytic biomass, whereas the Mixed treatment with 2 herbivore species had the lowest epiphyte biomass (Table 3).

\section{DISCUSSION}

Contrary to hypothesis H1a, Idotea had no measurable negative effects on Fucus growth rate (measured as increases in area and length of thallus). This is somewhat surprising, given the documented laboratory (Jormalainen et al. 2001, Hemmi et al. 2005) and field studies (e.g. Engkvist et al. 2004, Nilsson et al. 2004) demonstrating the negative effects of the grazing activities of Idotea on Fucus growth rate and cover. On the other hand, the similarity of the increases in area and length between the No grazer and Idotea only treatments may mask the effect of the Idotea grazing activities; this is because this herbivore, as well as grazing on Fucus itself, simultaneously reduces the epiphytic load on the Fucus, which in turn may have positively affected its growth. This possibility is supported by feeding preference studies showing that Idotea preferred filamentous algae over Fucus (Ravanko 1969, Goecker \& Kåll 2003, Orav-Kotta \& Kotta 2004). The positive effects of Idotea sp. on the growth of eelgrass likewise result from the isopod's ability to reduce the population of algal epiphytes (Williams \& Ruckelshaus 1993). Since no filamentous 
algae were left after treatment with Idotea only (Råberg \& Kautsky 2007b), it is possible that Idotea ate all available filamentous algae and pieces of Fucus tissue. Hence, the hypothesis that Idotea would increase the growth rate of Fucus by reducing the population of fouling epiphytes (H1b) may not have been upheld in this study because Idotea simultaneously grazed on Fucus itself.

The hypothesis that the gastropod Theodoxus would reduce the growth rate of Fucus, measured as increase in length, due to reduced nitrogen uptake (H2a) was not supported, since the nitrogen content was similar in the grazer treatments with and without Theodoxus. However, the hyaline hairs are only important for nutrient uptake in low-nutrient environments (Hurd et al. 1993). Thus, contrary to Jormalainen et al. (2003), who suggested that grazing Theodoxus inhibited nutrient uptake in Fucus, high nutrient concentrations in both the ambient and nutrient enriched treatments in the present study may have overshadowed any effect arising from grazing on hyaline hairs. The hypothesis that Theodoxus would increase the linear growth of Fucus thalli by reducing the population of growing epiphytes (H2b) was, however, confirmed. Other studies have also demonstrated the significance of Theodoxus as a grazer of fouling epiphytes, but with contrasting effects on Fucus growth (Jormalainen et al. 2003, Honkanen \& Jormalainen 2005). Our results (that Idotea had no effect while Theodoxus had a positive effect on Fucus growth rate) are partly supported by a field survey of Fucus, showing that gastropod but not crustacean grazing was positively correlated with Fucus cover (Worm et al. 1999).

It is possible that the quite different impacts of Idotea and Theodoxus on the linear growth of Fucus thalli (despite the fact that 2 grazers reduced epiphyte load by approximately the same amount) may occur because Idotea simultaneously grazed on Fucus itself, as mentioned previously. An alternative hypothesis is that herbivores utilized different algal species (Råberg \& Kautsky 2007b). While most of the remaining epiphytes in the treatments with Idotea only were microalgae (filamentous macroalgae were grazed away), those in treatments with Theodoxus-only consisted mainly of filamentous macroalgae (Råberg \& Kautsky 2007b). The higher growth rate of Fucus in treatments with Theodoxus thus suggests that epiphytic microalgae shade Fucus to a greater extent than filamentous macroalgal epiphytes. Hence, Theodoxus is an efficient grazer on harmful, shading epiphytes and is thus important for maintaining Fucus communities in the Baltic Sea.

Even though the presence of both Theodoxus and Idotea (i.e. the Mixed treatment) resulted in significantly lower epiphytic biomass, this reduction in epi- phytic load did not translate into an increase in Fucus thallus length (i.e. there was no significant difference in thallus length between the Mixed and Theodoxusonly treatments). Thus, the hypothesis that a complementarity effect (Loreau \& Hector 2001) should result in a higher growth rate (H3) could not be supported. There may be two reasons for this lack of enhanced growth, despite the significantly lower epiphytic load in this treatment. First, Idotea (as may have been the case in the Idotea-only treatment) counteracts the positive effect of the reduction of the epiphyte population by directly grazing on Fucus itself. Second, since Fucus is a slow-growing perennial algal species, the similar high growth rates in the Theodoxus-only and Mixed treatments may mean that inherent Fucus maximum growth rates had already been achieved in the treatment with only Theodoxus as a grazer. Thus, even though the Mixed treatment reduced the epiphytic load, and hence increased the light availability significantly more than the monocultural herbivore treatments, the inherently slow growth of Fucus hindered any additional growth in this treatment. The lack of increased plant biomass resulting from exposure to a higher diversity of grazers is also evident when combining 2 (Duffy \& Harvilicz 2001) or 3 (Duffy et al. 2001) species of grazing crustaceans. However, some studies have demonstrated increased plant growth in response to different herbivorous species compositions (Duffy et al. 2003, Hays 2005). In a study including 6 different grazer species, the biomass of eelgrass increased depending on species composition, but not on grazer diversity per se (Duffy et al. 2003). When the diversity was maximized, the previous growth facilitation in response to reduced epiphytic load was replaced by the suppression of eelgrass biomass due to direct grazing on the host plant (Duffy et al. 2003). Given that Idotea also eats Fucus, similar results might have been obtained had the present study incorporated other grazer species that competed with Idotea for the macroepiphytes, e.g. Gammarus spp. and other species of the genus Idotea. Hays (2005), who studied a crab and a shrimp species with and without nutrient addition, demonstrated that the higher growth rate of turtle grass subjected to a combination of grazer species was dependent on both nutrient level and eelgrass source population. However, the treatment with the grazers in combination also contained a higher biomass of grazers (Hays 2005). Hence, it was impossible to distinguish the cause of the increased eelgrass biomass, i.e. whether it was due to overall higher grazing pressure or to complementarity between the two herbivorous species (Hays 2005).

An increased nutrient level did not decrease the growth rate of Fucus (measured as growth in either area or length) as was hypothesized (H4), even though 
nutrient addition did increase the epiphytic load on Fucus. A meta-analysis of studies of seagrass beds demonstrated that the positive effect of grazers was comparable in magnitude to the negative effect of water column nutrient enrichment (Hughes et al. 2004). In the present study, however, grazing activity of the herbivores was the sole factor influencing Fucus growth rate.

In summary, different grazer species may have different capacities for facilitating the growth of large structuring macrophytes. Theodoxus, a common gastropod in the northern Baltic Sea, increased the growth rate of the ecologically important perennial brown alga Fucus. In contrast, even though the isopod Idotea reduced the epiphyte load by approximately the same amount as Theodoxus, Idotea grazing resulted in a Fucus growth rate as low as that in the treatment with no grazers present. When the two herbivorous species were mixed together, the epiphytic biomass was reduced even further, possibly due to a complementarity effect arising from resource partitioning between the species (Råberg \& Kautsky 2007b). However, this lower biomass of epiphytes on Fucus did not increase the linear growth of Fucus thalli any further; instead, growth remained at the level measured in the Theodoxus-only treatment. Unlike the absence of grazers, the high nutrient load in the nutrient enrichment treatments did not have any negative effect on Fucus growth rate. This further demonstrates the important role of grazing communities for the health and maintenance of Fucus belts, since low-nutrient conditions without grazers produced lower linear growth of Fucus thalli compared to that of Fucus in the high-nutrient treatment with Theodoxus present.

Acknowledgements. We thank P. Moksnes for valuable discussion of the experimental setup, and H. Hillebrand and S. Wikström for constructive discussion of the results and for commenting on the manuscript. We also thank V. Jormalainen and one anonymous reviewer whose comments greatly improved an earlier version of the manuscript. The research was financially supported by the MARBIPP programme, the Swedish Environmental Protection Agency, and the Stockholm Marine Research Centre.

\section{LITERATURE CITED}

Benedetti-Cecchi LPF, Pannacciulli F, Bulleri F, Moschella PS, Airoldi L, Relini G, Cinelli F (2001) Predicting the consequences of anthropogenic disturbance: large-scale effects of loss of canopy algae on rocky shores. Mar Ecol Prog Ser 214:137-150

Berger R, Henriksson E, Kautsky L, Malm T (2003) Effects of filamentous algae and deposited matter on the survival of Fucus vesiculosus L. germlings in the Baltic Sea. Aquat Ecol 37:1-11

Chapman ARO (1989) Abundance of Fucus spiralis and ephemeral seaweeds in a high eulittoral zone: effects of grazers, canopy and substratum type. Mar Biol 102: 565-572

Chopin T, Marquis PA, Belyea EP (1996) Seasonal dynamics of phosphorus and nitrogen contents in the brown alga Ascophyllum nodosum (L.) Le Jolis, and its associated species Polysiphonia lanosa (L.) Tandy and Pilayella littoralis (L.) Kjellman, from the Bay of Fundy, Canada. Bot Mar 39: 543-552

> Duffy JE (1990) Amphipods on seaweeds: partners or pests? Oecologia 83:267-276

> Duffy JE (2002) Biodiversity and ecosystem function: the consumer connection. Oikos 99:201-219

> Duffy JE, Harvilicz AM (2001) Species-specific impacts of grazing amphipods in an eelgrass-bed community. Mar Ecol Prog Ser 223:201-211

$>$ Duffy JE, Hay ME (1991) Food and shelter as determinants of food choice by an herbivorous marine amphipod. Ecology 72:1286-1298

Duffy JE, Hay ME (2000) Strong impacts of grazing amphipods on the organization of a benthic community. Ecol Monogr 70:237-263

Duffy JE, MacDonald KS, Rhode JM, Parker JD (2001) Grazer diversity, functional redundancy, and productivity in seagrass beds: an experimental test. Ecology 82:2417-2434

> Duffy JE, Richardson JP, Canuel EA (2003) Grazer diversity effects on ecosystem functioning in seagrass beds. Ecol Lett 6:637-645

Engkvist R, Malm T, Nilsson J (2004) Interaction between isopod grazing and wave action: a structuring force in macroalgal communities in the southern Baltic Sea. Aquat Ecol 38:403-413

Goecker ME, Kåll SE (2003) Grazing preferences of marine isopods and amphipods on three prominent algal species of the Baltic Sea. J Sea Res 50:309-314

Hays CG (2005) Effect of nutrient availability, grazer assemblage and seagrass source population on the interaction between Thalassia testudinum (turtle grass) and its algal epiphytes. J Exp Mar Biol Ecol 314:53-68

> Hemmi A, Mäkinen A, Jormalainen V, Honkanen T (2005) Responses of growth and phlorotannins in Fucus vesiculosus to nutrient enrichment and herbivory. Aquat Ecol 39: 201-211

> Honkanen T, Jormalainen V (2005) Genotypic variation in tolerance and resistance to fouling in the brown alga Fucus vesiculosus. Oecologia 144:196-205

Hughes AR, Bando KJ, Rodriguez LF, Williams SL (2004) Relative effects of grazers and nutrients on seagrasses: a meta-analysis approach. Mar Ecol Prog Ser 282:87-99

Hurd CL, Galvin RS, Norton TA, Dring MJ (1993) Production of hyaline hairs by intertidal species of Fucus (Fucales) and their role in phosphate uptake. J Phycol 29:160-165

> Jormalainen V, Honkanen T, Heikkilä N (2001) Feeding preferences and performance of a marine isopod on seaweed hosts: cost of habitat specialization. Mar Ecol Prog Ser 220: 219-230

> Jormalainen V, Honkanen T, Koivikko R, Eränen J (2003) Induction of phlorotannin in a brown alga: defence or resource dynamics? Oikos 103:640-650

Kangas P, Autio H, Hällfors G, Luther H, Niemi Å, Salemaa H (1982) A general model of the decline of Fucus vesiculosus at Tvärminne, south coast of Finland in 1977-81. Acta Bot Fenn 118:1-27

> Loreau M, Hector A (2001) Partitioning selection and complementarity in biodiversity experiments. Nature 412:72-76

> Nilsson J, Engkvist R, Persson LE (2004) Long-term decline and recent recovery of Fucus populations along the rock shores of southeast Sweden, Baltic Sea. Aquat Ecol 38:587-598 
Orav-Kotta H, Kotta J (2004) Food and habitat choice of the isopod Idotea baltica in the northeastern Baltic Sea. Hydrobiologia 514:79-85

Pedersen MF, Borum J (1996) Nutrient control of algal growth in estuarine waters. Nutrient limitation and the importance of nitrogen requirements and nitrogen storage among phytoplankton and species of macroalgae. Mar Ecol Prog Ser 142:261-272

Råberg S, Kautsky L (2007a) A comparative biodiversity study of the associated fauna of perennial fucoids and filamentous algae. Estuar Coast Shelf Sci 73:249-258

Råberg S, Kautsky L (2007b) Consumers affect prey biomass and diversity through resource partitioning. Ecology 88: 2468-2473

Ravanko O (1969) Benthic algae as food for some invertebrates in the inner part of the Baltic. Limnologica 7:203-205

Schramm W, Nienhuis PH (1996) Marine benthic vegetation: recent changes and the effects of eutrophication. Ecological Studies 123. Springer, Heidelberg

Valiela I, McClelland J, Hauxwell J, Behr PJ, Hersh D, Fore-

Editorial responsibility: Kenneth Heck,

Dauphin Island, Alabama, USA man K (1997) Macroalgal blooms in shallow estuaries: controls and ecophysiological and ecosystem consequences. Limnol Oceanogr 42:1105-1118

Williams SL, Ruckelshaus MH (1993) Effects of nitrogen availability and herbivory on eelgrass (Zostera marina) and epiphytes. Ecology 74:904-918

Worm B, Lotze HK, Boström C, Engkvist R, Labanauskas V, Sommer U (1999) Marine diversity shift linked to interactions among grazers, nutrients and propagule banks. Mar Ecol Prog Ser 185:309-314

Worm B, Lotze HK, Sommer U (2000a) Coastal food web structure, carbon storage, and nitrogen retention regulated by consumer pressure and nutrient loading. Limnol Oceanogr 45:339-349

Worm B, Reusch BH, Lotze HK (2000b) In situ enrichment: methods for marine benthic ecology. Int Rev Hydrobiol 85: 359-375

Worm B, Barbier EB, Beaumont N, Duffy JE and others (2006) Impacts of biodiversity loss on ocean ecosystem services. Science 314:787-790

Submitted: February 6, 2007; Accepted: January 25, 2008 Proofs received from author(s): May 27, 2008 